\title{
Solar Radiation Distribution inside a Greenhouse Prototypal with Photovoltaic Mobile Plant and Effects on Flower Growth
}

\author{
Andrea Colantoni ${ }^{1, *}$ (1) , Danilo Monarca ${ }^{1}$, Alvaro Marucci ${ }^{1}$, Massimo Cecchini ${ }^{1}$ (1), \\ Ilaria Zambon ${ }^{1}$ (D), Federico Di Battista ${ }^{2}$, Diego Maccario ${ }^{2}$, Maria Grazia Saporito ${ }^{1,3}$ and \\ Margherita Beruto 2 (iD \\ 1 Department of Agricultural and Forestry scieNcEs (DAFNE), Tuscia University, Via San Camillo de Lellis, \\ 01100 Viterbo, Italy; monarca@unitus.it (D.M.); marucci@unitus.it (A.M.); cecchini@unitus.it (M.C.); \\ ilaria.zambon@unitus.it (I.Z.) \\ 2 Regional Institute for Floriculture, Via Carducci 12, 18038 Sanremo, Italy; dibattista@regflor.it (F.D.B.); \\ maccario@regflor.it (D.M.); beruto@regflor.it (M.B.) \\ 3 Ministero Delle Politiche Agricole Alimentari e Forestali (MIPAAF), Via Venti Settembre 20, \\ 00187 Rome, Italy; mg.saporito@politicheagricole.it \\ * Correspondence: colantoni@unitus.it; Tel.: +39 076-1357356
}

Received: 13 February 2018; Accepted: 14 March 2018; Published: 18 March 2018

\begin{abstract}
The diffusion of renewable energy requires the search for new technologies useful for obtaining good energy and production efficiency. Even if the latter is not always easy to obtain, the integration of photovoltaic panels on the roof of greenhouses intended for floriculture can represent an alternative. The present paper evaluates climatic conditions inside a greenhouse, in which $20 \%$ of its roof surface has been replaced with mobile photovoltaic (PV) panels. The PV system implemented in this study can vary the light energy collection surface in relation to the degree of insolation. The aim is to observe the shading effects of the PV system on the growth of several varieties of flowers (iberis, mini-cyclamens and petunias) to ensure the use of solar energy as an income integration deriving from floricultural production. In fact, in agronomic terms, it has ensured: (i) to be able to shade the underlying environment in most lighting conditions; and (ii) to let through more light when it is required for the needs of crop plants or in cloudy weather. Results have described the distribution of solar radiation, variability of temperature and humidity and lighting in a solar year and the observed outcomes on floristic production.
\end{abstract}

Keywords: solar radiation; photovoltaic plant; greenhouse; renewable energy; flowers growth

\section{Introduction}

Renewable sources can be used in the agricultural field [1,2]. Among these, the most widely used are: (i) photovoltaic panels; (ii) micro or small wind turbines to produce electricity; and (iii) solar-thermal for the heat production [3-5]. In recent years, thanks to government grants, applied technologies have undergone rapid evolutionary processes, leading to new efficient and economically-competitive products usable also in the agricultural sector [6-8].

Based on these premises, the present paper examines the possibility of using solar greenhouses with a dual purpose, such as for both energy production and floricultural products. Among the systems of exploitation of renewable sources of energy, the photovoltaic system (PV) has been strongly investigated over the last five years, as well as by several scientific research activities [9-11]. Building PV greenhouses is technically feasible from a construction point of view; however, realizing solar greenhouses able to guarantee an efficient agricultural production, in addition to electricity production, 
is far from a simple task $[12,13]$. Currently the application of greenhouse technology in floriculture is rapidly expanding around the world [14]. Successful greenhouse production is derived from the possibility of: (i) providing a favorable ground for the cultivation [15]; (ii) ensuring a controlled microclimate; (iii) avoiding adverse weather conditions [16]; (iv) preventing pests and diseases [17]; and (v) improving the quality of the crop [18]. Greenhouse crops are one of the most intensive activities of the agricultural sector [19] in terms of production and energy consumption and operating costs [10,20-22]. Agronomic research, construction technology concerning PV greenhouses and the choice of transparent roofing materials are now increasingly oriented to reduce artificial energy usage, to contain production costs, and to reduce environmental impacts [23-28].

Since greenhouses occupy agricultural land [29], the integration of production plants of solar energy on the greenhouse roof can be the most sustainable solution $[10,30]$. However, some determinants must be considered. The factors that strongly influence the design of a solar greenhouse for floricultural use are: (i) the shadow projection of PV panels on the ground; (ii) the amount of photosynthetically active radiation present within the structure; and (iii) the design of protected installations, able to ensure sufficient flexibility and to allow changes in cultivation target in relation to changing market demands [31-35]. In fact, farmers, who have a limited area for PV systems, are forced to use the roofs of greenhouses, causing many problems related to day-lighting, such as loss of color and smaller size of products collected [13,30]. In those circumstances, the main problem of the greenhouse system consists of the entity of the economic investment requested at the beginning $[1,36,37]$. This commitment seems more compatible with industry rather than with traditional agriculture. The cost of equipping a greenhouse lies between $€ 40 / \mathrm{m}^{2}$ and $€ 200 / \mathrm{m}^{2}$ depending on the climatic area (where the structure is built), the technological level and chosen infrastructure, as well as the type of crop to be produced. These factors affect business models. In fact, the depreciation cost imposes an ultra-intensive production system (with a high load of labor and energy) and the choice of high-yield crops and with considerable added value. In a mixed system, such as that in the present work, where a part of the investment concerns the photovoltaic chain, the less intensive and extended production systems become available to a wider range of cultivated species, from an economic point of view.

From this perspective, an enlargement of the cultivable species might be expected. Feasibility studies could also concern crops not yet considered due to the lack of profitability. In a protected environment (due to the controlled microclimate that is recreated in a greenhouse), the light is a critical and limiting factor for most of the cultivated species, like others, such as the temperature or the relative humidity [38]. In recent years, new opportunities in the energy market and the incentives related to the construction of photovoltaic plants, as well as the progressive reduction of purchase costs of most PV materials, have encouraged the implementation of PV systems mounted on greenhouses (in their total or partial replacement) $[6,33,39]$. The acceleration of the market has given rise to problems of coexistence between the electric and the agricultural production, in competition with the same source of energy, as noted in the recent past $[12,13]$. The biggest problem that designers and farmers must face is the light inside the greenhouse [37]. PV panels project shadow cones on the ground: the amount of photosynthetically active radiation reaching the crop cannot depend only on the limiting conditions imposed by the photovoltaic installation, but also the actual interest that that culture has for the market and the product quality obtained $[1,32,38]$. Development of materials, and still more the tax legislation for access to the forms of incentive, have induced the progressive change of PV installations on greenhouses [37]. It has gone from structures specifically built as a function of the PV system with mono-pitched or bi-pitched roof, $100 \%$ covered by totally opaque PV panels, up to realizations gradually more attentive to the needs of agricultural crops. This type of planning leads to the creation of more luminous greenhouse structures than those currently available in the market [37]. In addition, efficient solutions for air circulation and cooling of the PV panels have been introduced, providing "modular" solar panels with roof structures of the greenhouse [40]. 
The present paper evaluates climatic conditions inside a greenhouse, in which $20 \%$ of its roof surface has been replaced with mobile PV panels, able to diverge the light energy collection surface according to the degree of insolation. The purpose is to detect the shading effects of PV systems on the growth of some flowers (iberis, mini-cyclamens and petunias), guaranteeing an optimal underlying environment in most lighting conditions and letting through more light when it is required for the needs of crop plants (or in cloudy weather). Furthermore, it is expected that this system also delivers an income integration to farmers.

\section{Materials and Methods}

\subsection{Location}

The greenhouse prototype is located at the Regional Institute for Floriculture in Sanremo (IRF), Liguria region, North-East Italy (geographical references: $43^{\circ} 49^{\prime} 3^{\prime \prime} \mathrm{N}-7^{\circ} 45^{\prime} 50^{\prime \prime}$ E with an axis of orientation of the roof ridge of $351^{\circ} \mathrm{N}$ ) (Figure 1).
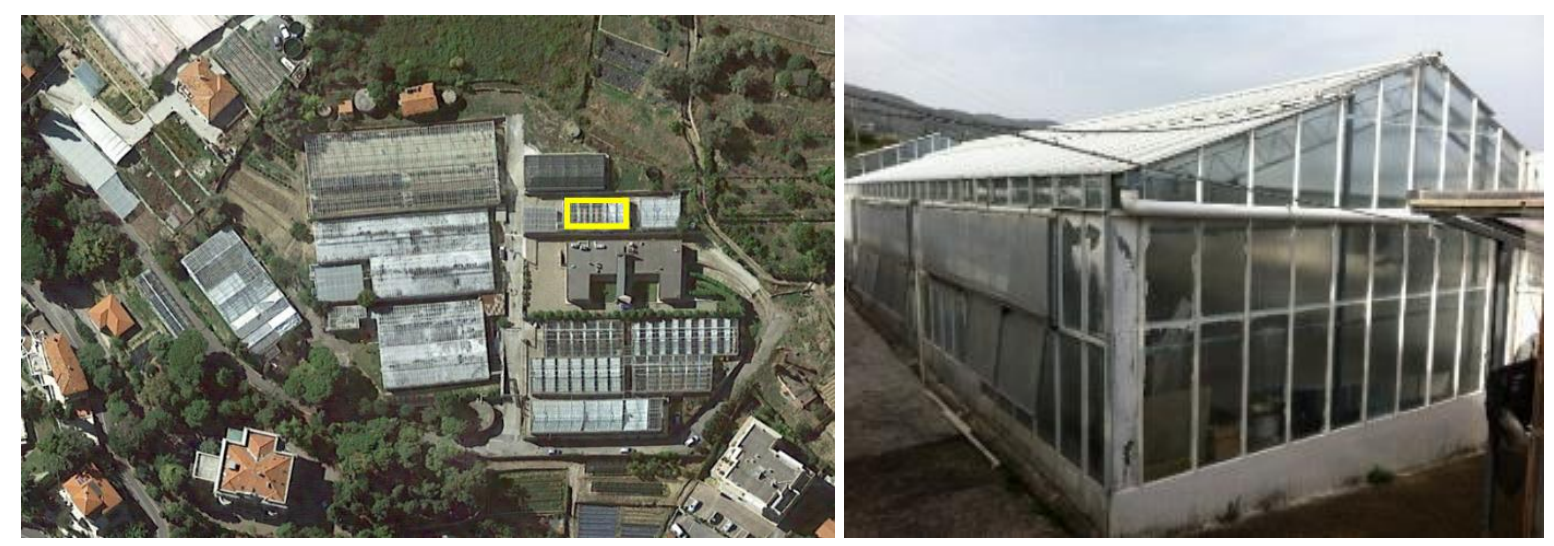

Figure 1. Location of the greenhouse model (left) and its external overview (right).

\subsection{The Prototype}

The greenhouse chosen for the experimental study was built in 1985. It is a glass single span greenhouse with ridge ventilators, with the following dimensions: $9 \mathrm{~m}$ width; $12.44 \mathrm{~m}$ length; $3.53 \mathrm{~m}$ height at the sides and $5.15 \mathrm{~m}$ ridge height. The total surface area of the roof is approximately $119 \mathrm{~m}^{2}$, while the PV surface area is $24 \mathrm{~m}^{2}$. The area covered by PV panels (approximatively $20 \%$ of the roof covering) was made up of a part of fixed panels (26 panels) and a part of the underlying mobile panels (26 panels), moving on a rail system by means of an electric motor, which increase the PV absorption surface when the sun is present.

On the greenhouse roof, an innovative PV solar system ( $3016 \mathrm{~W})$ with movable panels has been mounted. It consists of twenty-six PV fixed modules and twenty-six PV mobile modules mounted on the top towards to the east. The PV modules have a power of $58 \mathrm{~W}$. Twenty-six fixed glass panels were removed and, inside the greenhouse, a rail system was set on which the movable panels have been installed. The movement was guaranteed by a ratchet electric tire (Blinky brand, mod. 49463-02/6) with $12 \mathrm{~V}$ and a power of $150 \mathrm{~W}$. An inverter Abb Power One PVI 3.0 Out Tl was installed for the network connection, having $3000 \mathrm{~W}$ with dual input Mppt CEI 0-21 (Figures 2 and 3). 


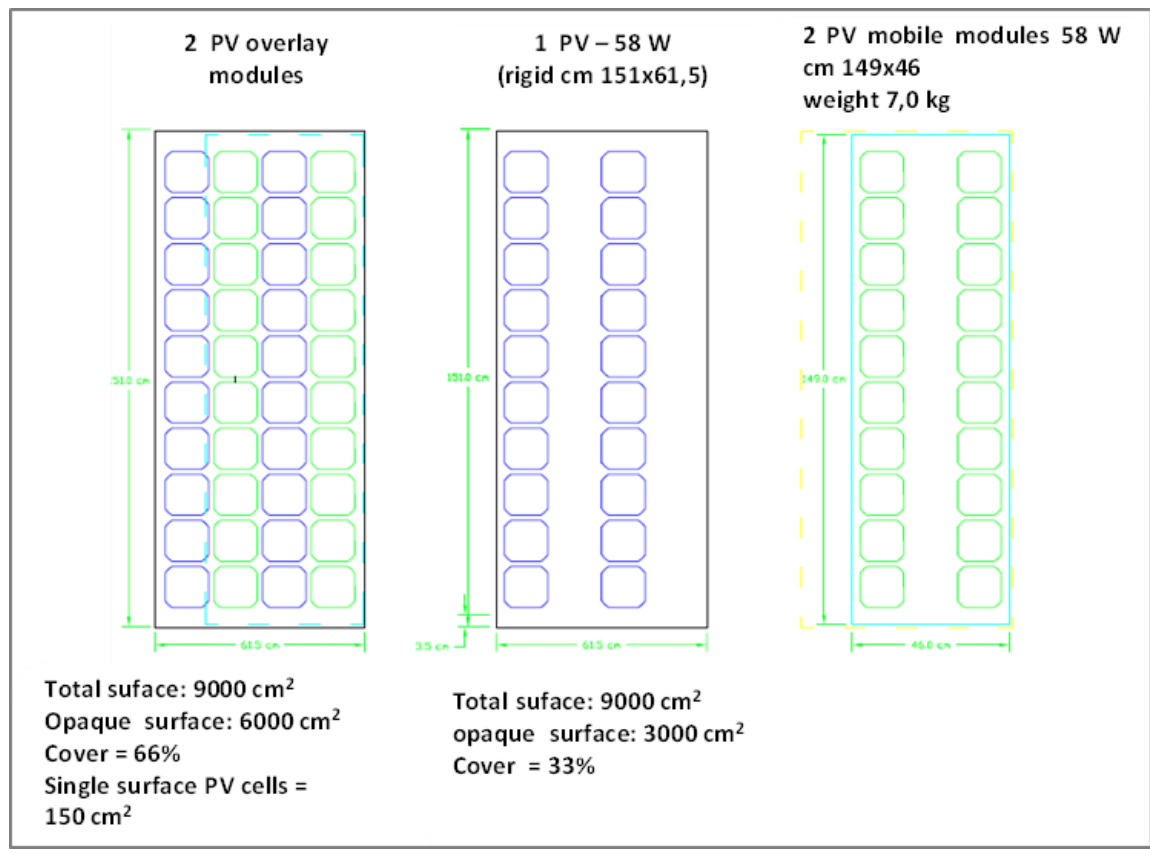

Figure 2. Technical drawing of photovoltaic (PV) panels with variable shading.

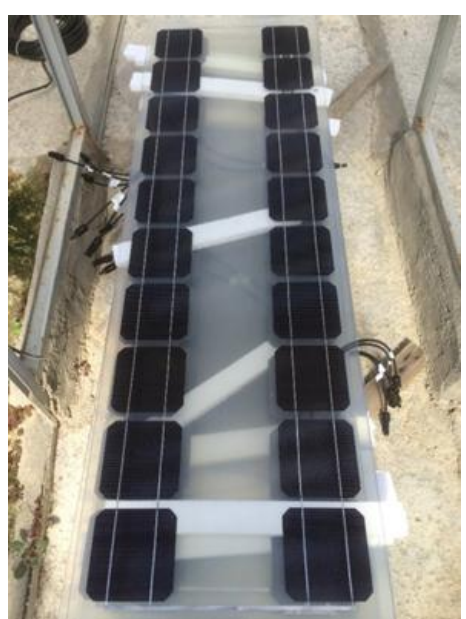

(a)

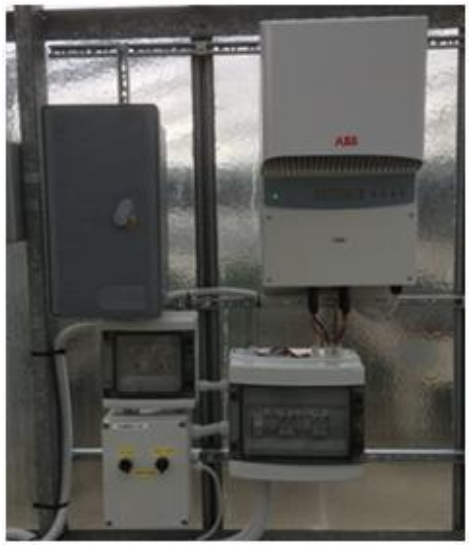

(c)

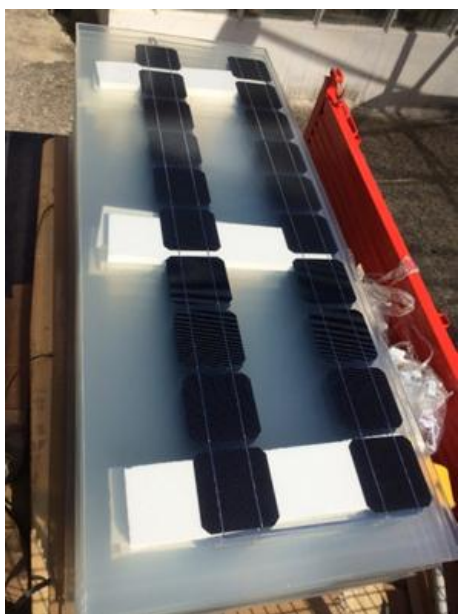

(b)

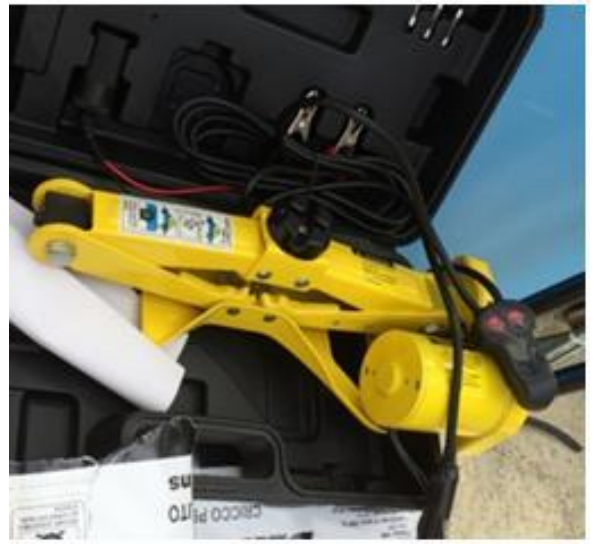

(d)

Figure 3. Cont. 


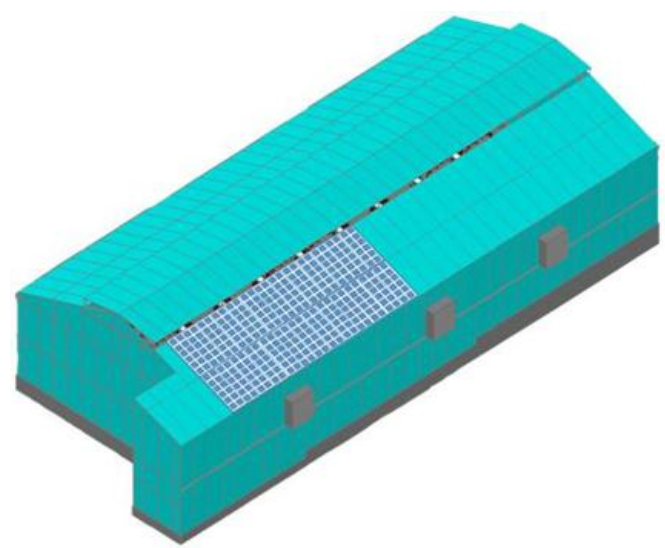

(e)

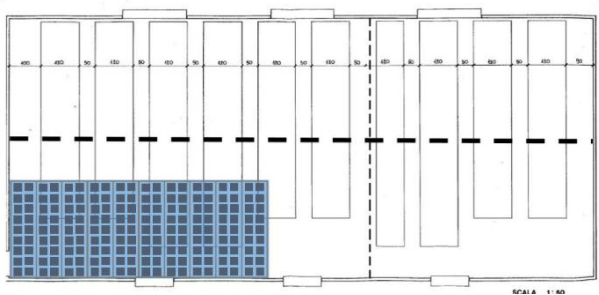

(f)

Figure 3. Features of the greenhouse: fixed panels (a); mobile panels (b); inverter (c); engine used for the panels movement (d); 3D diagram of the greenhouse model, highlighting the part which will be affected by the PV roof (e); diagram of the greenhouse prototype structure (f).

Different challenges are faced during the design of the prototype. The moving system of panels initially encountered some difficulties during its installation and calibration, due to the inclination of flap height and weight of the underlying panels block that would have to run on the rail. In mid-May 2016, the prototype of PV mobile panels plant was completed.

The proposed system allows to control the shading in an active way, continuing to have a high-quality photovoltaic production (compared to a standard system with fixed shading to $50 \%$ ) as:

- during sunny days, when the PV production is greater, it is possible to use the maximum shading of $66 \%$ (which exhibits greater active area compared to the fixed one);

- on cloudy days, there is a certain loss of electrical energy (compared to a standard system with shading 50\%). However, on the other hand, there is an advantage from the viewpoint of the greenhouse performance, with a greater light passage (33\% of shading). The movement system allows the variation from $33 \%$ to $66 \%$, by translating the PV mobile module (only about $25 \mathrm{~cm}$ ) placed below the fixed one.

Regarding the light transmission of the glazing matrix of semi-transparent PV modules, when fixed and mobile PV modules are in the overlapping status, the transparent part of the PV modules is equipped with double glazing. Following the technical characteristics, about $30 \%$ of the light is dissipated by double glazing.

\subsection{Environmental Measures}

The environmental conditions of the greenhouse during the experimental trial were assessed by data on temperature and relative humidity $\left(\mathrm{T}^{\circ} \mathrm{C}, \mathrm{ru} \%\right.$ ) and lighting measurements, photosynthetically active radiation (PAR), Radiation Total, illumination, UVA). These latter ones were performed by means of two sets of sensors, located in the two different cultivation areas (under photovoltaic area-PV and out of photovoltaic area-Control).

A computerized system ( $\mu$ Agricomp-DL-Agricontrol SnC, 17031 Albenga, Savona, Italy) was used for the measurement and registration of temperature, relative humidity and brightness, global solar radiation, PAR and UVA radiation (Figure 4). The photometric and radiometric probes used are professional instruments (Delta Ohm, 35030 Caselle di Selvazzano, Padova, Italy) as follows:

- LP PHOT 03 (measuring range of 0-100,000 lux with a resolution of both 40 lux from 0 to 10,000 lux and 400 lux from 10,000 to 100,000 lux): it measures illuminance (lux), defined as the ratio between the luminous flux (lumens), passing through a surface, and the surface area of the area considered $\left(\mathrm{m}^{2}\right)$; 
- LP RAD 03 (measuring range of $0-1 \mathrm{~W} / \mathrm{m}^{2}$ with a resolution of $1 \mathrm{~W} / \mathrm{m}^{2}$ from 0 to $250 \mathrm{~W} / \mathrm{m}^{2}$ and of $4 \mathrm{~W} / \mathrm{m}^{2}$ from 25 to $\left.1 \mathrm{~W} / \mathrm{m}^{2}\right)$ : it measures the irradiance $\left(\mathrm{W} / \mathrm{m}^{2}\right)$ defined as the ratio between the energetic flux $(\mathrm{W})$, passing through a surface, and the surface area of the area considered $\left(\mathrm{m}^{2}\right)$ in the spectral region VIS-NIR $(40 \mathrm{~nm}-1.050 \mathrm{~nm})$;

- LP PAR (measuring range of $0-1.5-\mathrm{Mol} / \mathrm{m}^{2} / \mathrm{sec}$ ) and PPF (Photosynthetic Photons Flux, with a resolution of 1 PPF from 0 to 250 PPF and 6 PPF from 250 to 1500 PPF): it measures the number of photons in the spectral region ranging from $400 \mathrm{~nm} 720 \mathrm{~nm}$, arriving in a second on a surface;

- LP UVA 03 (measuring ranges from 0 to $200 \mathrm{~W} / \mathrm{m}^{2}$ with a resolution of $1 \mathrm{~W} / \mathrm{m}^{2}$ ): it measures global irradiance in the UVB spectral region on a flat surface $\left(\mathrm{W} / \mathrm{m}^{2}\right)$. Particularly, the spectral sensitivity of the instrument is centered at $305 \mathrm{~nm}$ with a bandwidth (FWHM) of $5 \mathrm{~nm}$.

Data were analyzed by using the statistical software Statgraphics Centurion XVI, The Plains, Virginia.

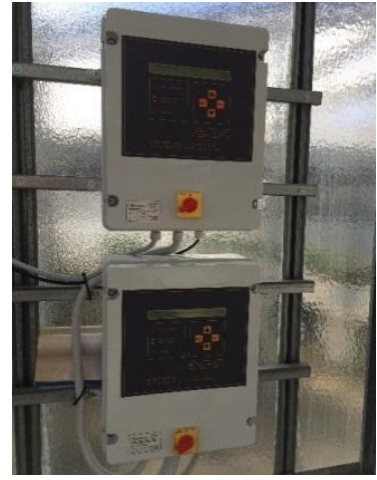

(a)

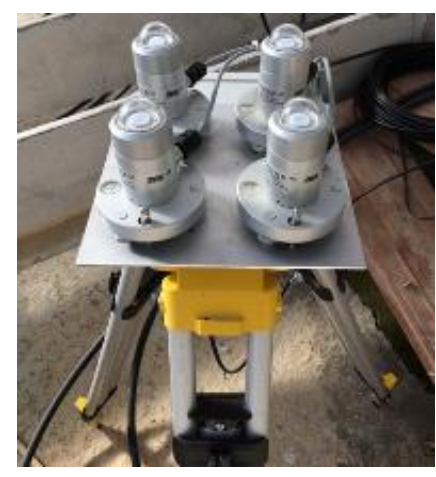

(b)

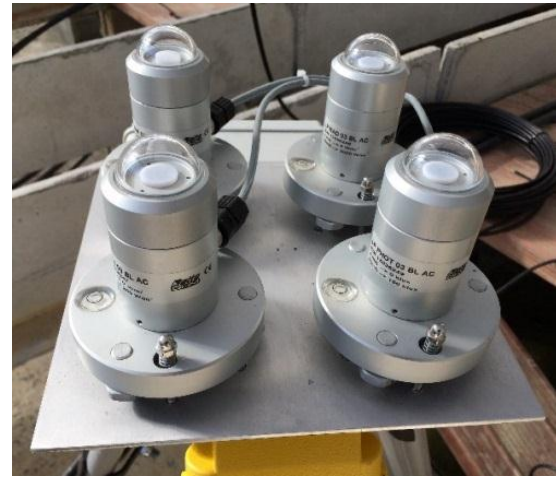

(c)

Figure 4. Data logging computer (a); group of sensors (b); and details of sensors (c).

To better highlight the reduction of brightness under PV condition, $\alpha$ variable was considered as follow:

$$
\alpha=[(\mathrm{xc}-\mathrm{xpv}) / \mathrm{xc}] * 100
$$

where:

$x c=$ brightness measurements (illuminance, irradiance and PAR) at control conditions, $x p v=$ brightness measurements (illuminance, irradiance and PAR) at PV conditions when $\alpha=0$ the light conditions are the same for the two treatments (control and PV), greater value of $\alpha$ indicated the reduced brightness conditions achieved under PV.

\subsection{Plant Materials and Agronomical Trial}

Plant growth under the "model greenhouse" was followed to infer the agronomical performance of different crops chosen as plant models. For this, plants grown directly under the PV panels were evaluated and their growth was compared to the behavior of a similar plant grown in the same climate greenhouse but without the PV panels. The agronomical trial start at week 29/16 (18 July 2016) and ended 38/16 (22 September 2016), (total 9 weeks of cultivation).

Only half of the plants were under PV cover. Mini-cyclamens, iberis and petunias were chosen based on seasonal availability, their importance for the floristic market and their adaptability to our environmental conditions.

The seedlings were purchased by Sentier (31010 Moriago della Battaglia, Vidor, Treviso) and arrived at our institute at the week 28/16. The following varieties were considered: Ciclamen persicum 'S.S. Verano ${ }^{\circledR \prime}$ 'Dark Violet, Petunia grandiflora 'Nana GP F1' red and Iberis sempervirens 'Montreaux' white. 
As described in the prototype paragraph, before the beginning of the experiment, seedlings were transferred to $12 \mathrm{~cm}$ diameter pots, filled with "Pomix 2" (Turco Silvestro S.N.C., Albenga, SV-Italy) which is a substrate containing Irish peat, blond peat, pumice stone (3-8 $\mathrm{mm}$ ), clay and slow release mineral fertilizer (Figure 5). Water and nutrient supply has been guaranteed by an automatic drop-flow irrigation system (irrigation on alternate days, 2 times a day; fertilizer ratio N:P:K equal to 1:0.5:2).

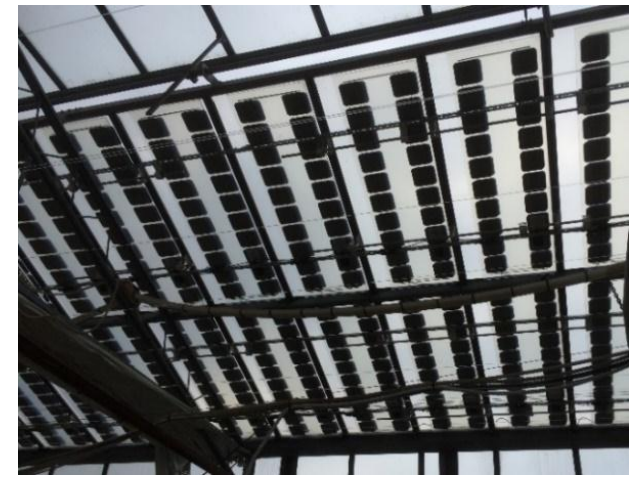

(a)

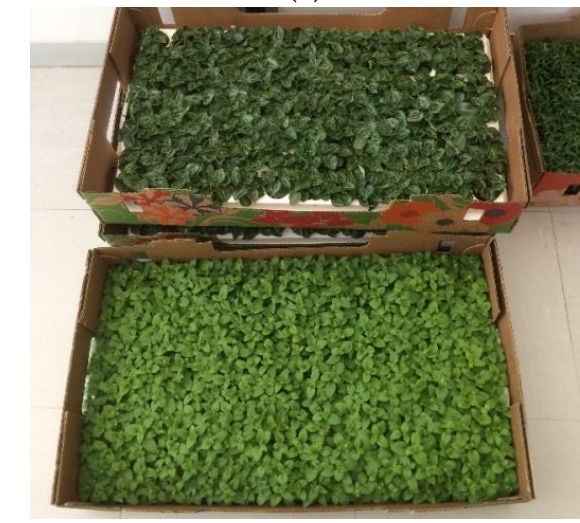

(c)
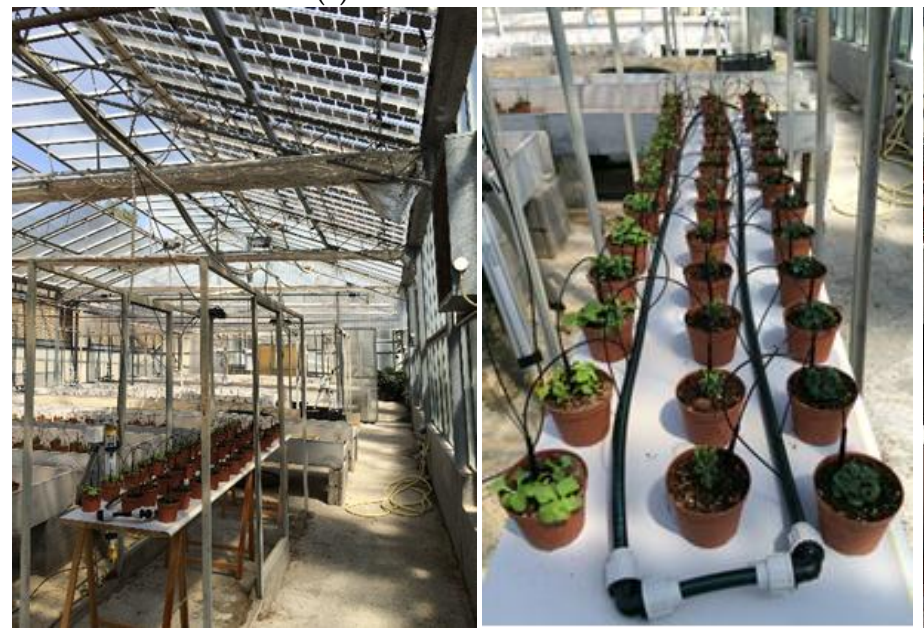

(e)

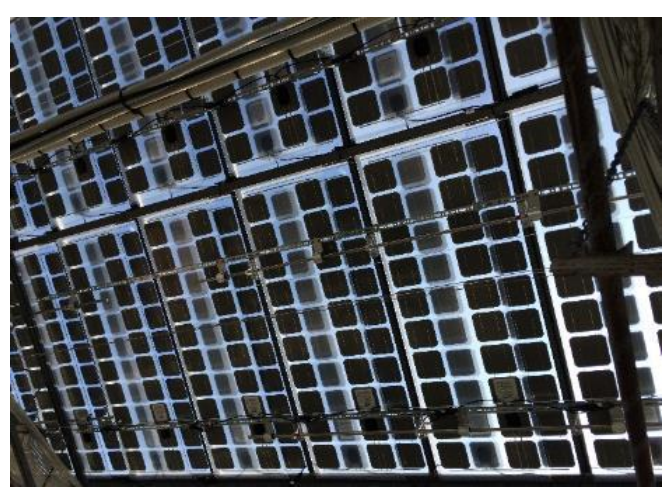

(b)

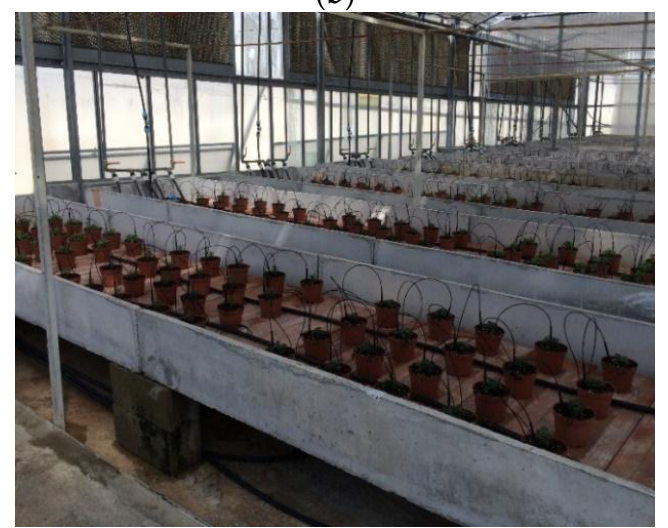

(d)

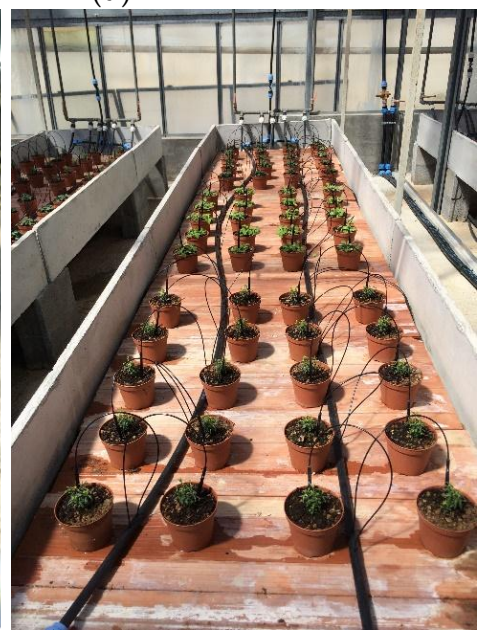

Figure 5. Experimental stage: complete panel diagram (overlapping panels) (a); complete mobile PV system (maximum capture of light radiation) (b); seedling on arrival in commercial plug tray (c); plants in the greenhouse prototype (d); plants during the trial (e).

Thirty plants by species (ninety in total) were evaluated for testing; one half was placed under the PV panels the other half was placed under normal lighting conditions. For each treatment (PV and control) 
5 plants have been considered and three replications were performed. Data were statistically analyzed according to multifactor analysis of variance (Statistical software Statgraphics Centurion XVI).

The following parameters have been considered to evaluate the plant growth:

- plant height;

- plant diameter;

- number of flowers/plant. In the case of iberis, the number of flower buds was counted since no blooming was scored for both treatments (PV and control).

\section{Results}

\subsection{Data Distribution Inside the Greenhouse}

To highlight the different light conditions under PV treatment, the trend of brightness from week 34 to week 37 (on week basis) was reported (Figures 6-10). Data on the PV-generated electrical energy per greenhouse land area throughout the cultivation period refers to $\mathrm{kWh} \mathrm{m}^{-2}$ week $^{-1}$.

The significant reduction of brightness values at week 37 recorded also for control treatment could be ascribed to a particularly cloudy period, which influenced the incoming radiation in the greenhouse; this effect has also been confirmed with the temperature data.

As expected, the PV conditions reduced the brightness. However, a different reduction could be scored according to the light measurements.

Under our experimental conditions PV panels on a part of the greenhouse roof and orientation and structure of the prototype, it was possible to infer that:

- the amount of incident light per unit area is about two times higher under the control area compared to the PV treated area;

- the total radiation (RAD) and the PAR were reduced of about $30 \%$ and $20 \%$ respectively under PV treatment.

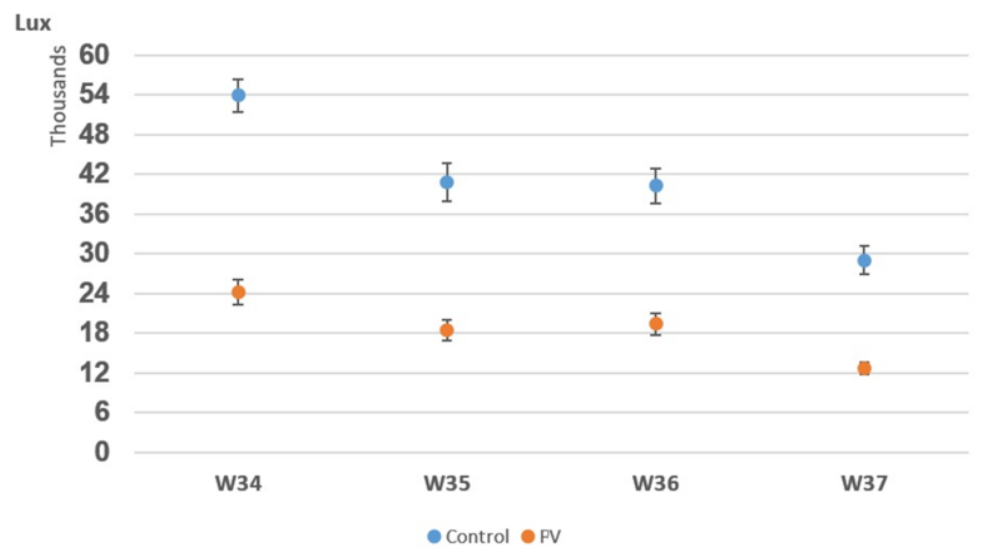

Figure 6. Illuminance data (average per week) collected between 22 August 2016 and 18 September 2016 in the control zone and in the PV area. 


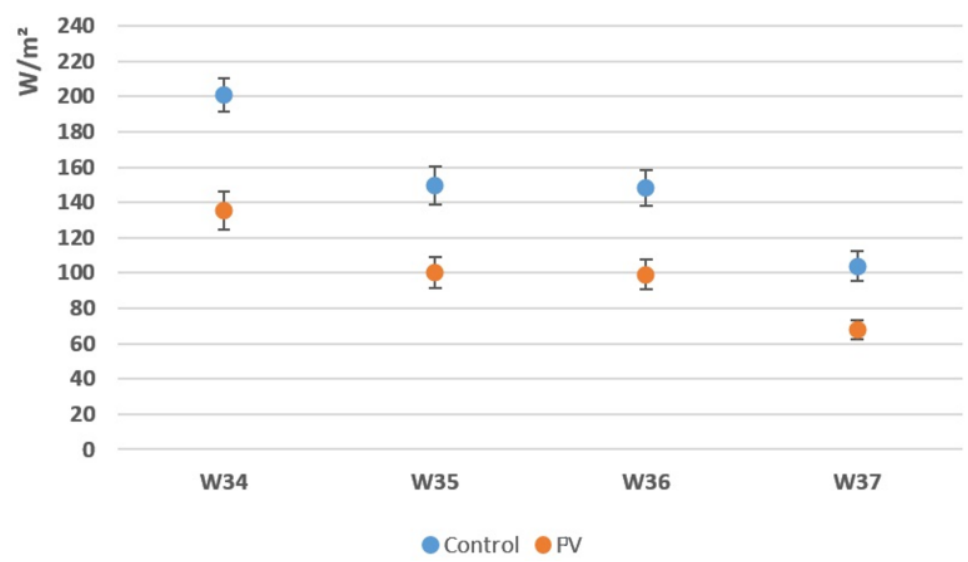

Figure 7. Solar radiation data (average per week) measured between 22 August 2016 and 18 September 2016 in the control zone and in the PV area.

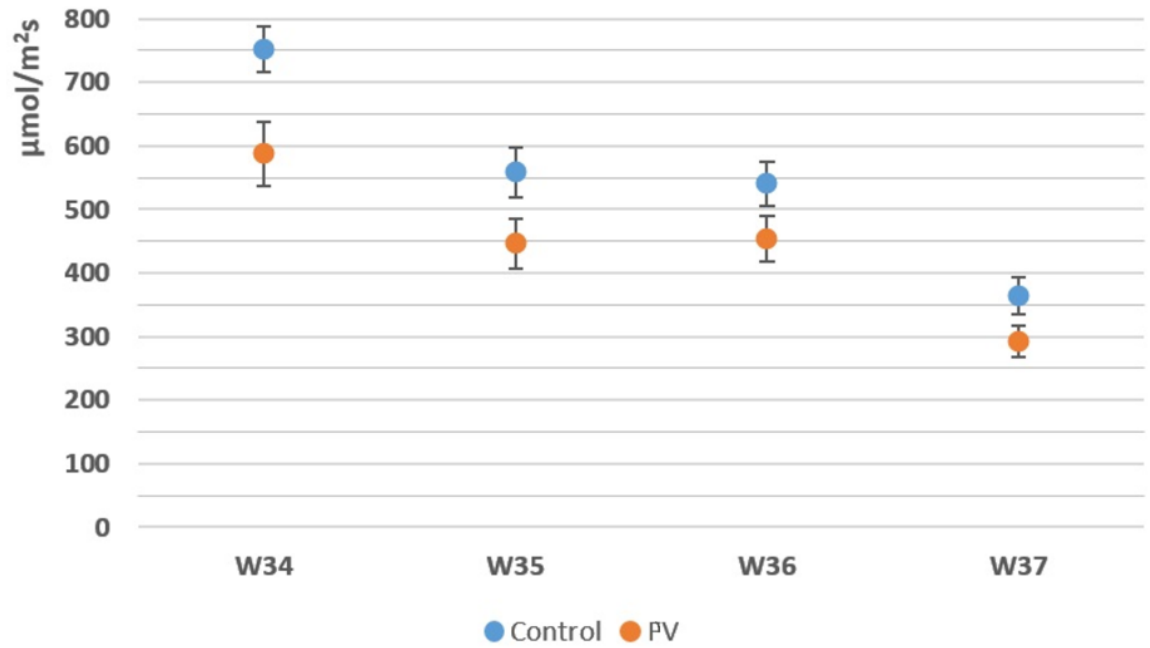

Figure 8. PAR data (average per week) measured between 22 August 2016 and 18 September 2016 in the control zone and in the PV area.

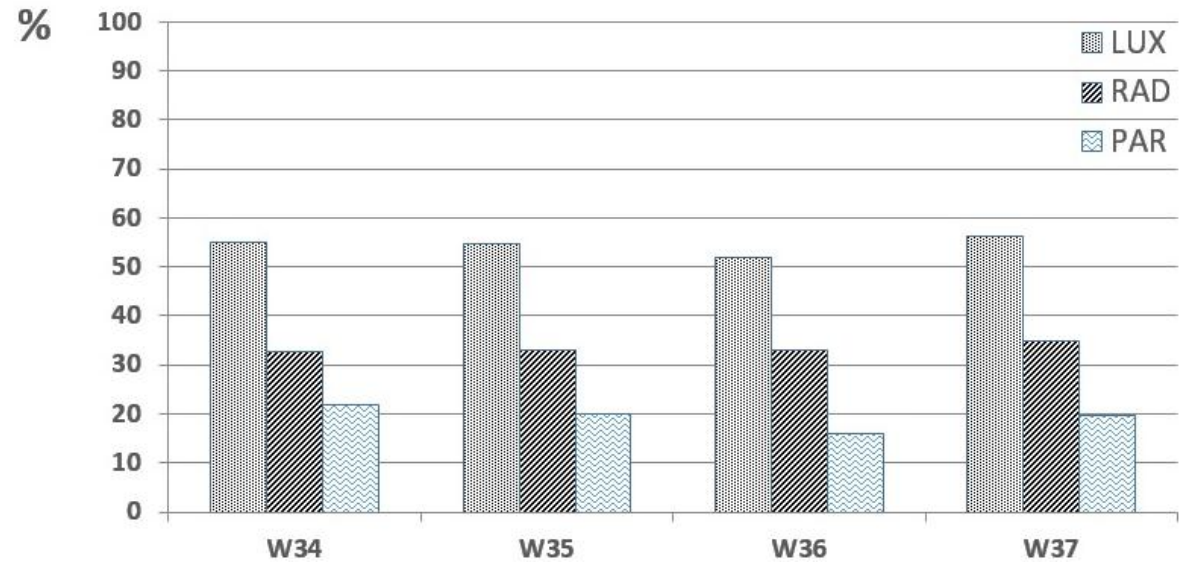

Figure 9. " $\alpha$ variable", that expresses the percentage ratio of the light data difference between control and PV, compared to control. When $\alpha=0$ the light conditions are the same for the two treatments (control and PV), greater value of $\alpha$ indicated the reduced brightness conditions achieved under PV. 


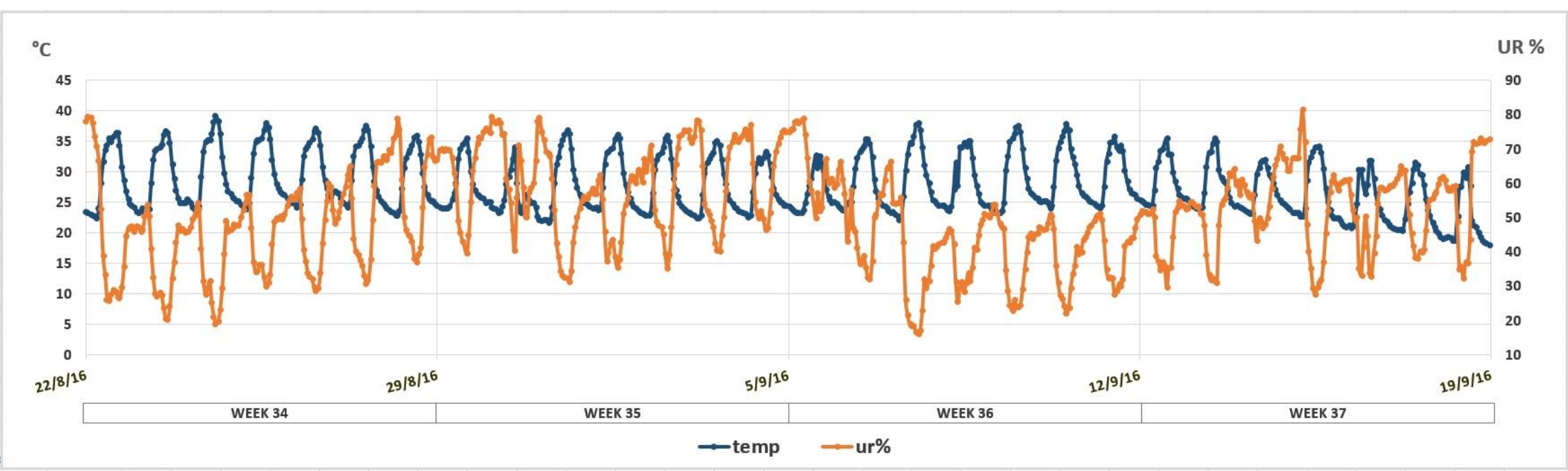

Figure 10. Temperature and ur\% data, in the greenhouse, collected in the period related to brightness measurements. The significant drop in temperature seen in the last week $(37 \mathrm{~W})$ is due to a particularly cloudy period. 


\subsection{Crops Production and Relation with Greenhouse Plant}

No blooming was recorded for iberis over the trial period. This was true for the control and for the seedling grown under PV. From the count of the flower-induced buds, however, no differences were detected between control and PV treated plants. In addition, the vegetative growth was not influenced by PV treatment (Figures 11 and 12). A similar agronomical behavior was detected for petunias, for which a complete blooming was, vice versa, observed (Figures 13 and 14). Then, it was inferred that the flowering lacking in iberis was rather due to the high greenhouse temperature (maximum temperatures up to $40^{\circ} \mathrm{C}$ and, for the trial period always between 25 and $35^{\circ} \mathrm{C}$ ) and no influence of our prototype could be ascribed.

Mini-cyclamen growth was affected by PV system (data not shown). Indeed, under PV prototype, an enhanced plant diameter in centimeters $(\mathrm{cm})$ and a reduced flowers/plant could be observed (Figures 15 and 16). Besides, a flowering precocity, about one/two weeks, was also detected.

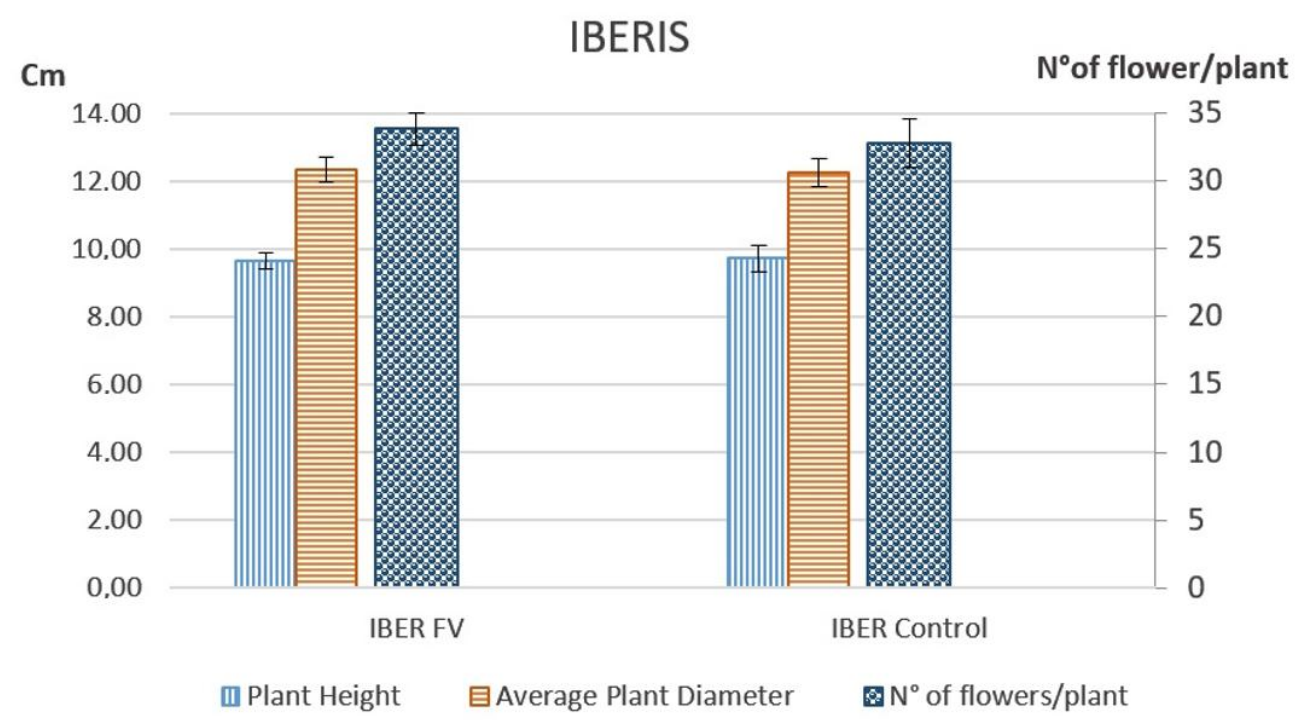

Figure 11. Iberis: analysis of plant growth parameters at the end of the trial.
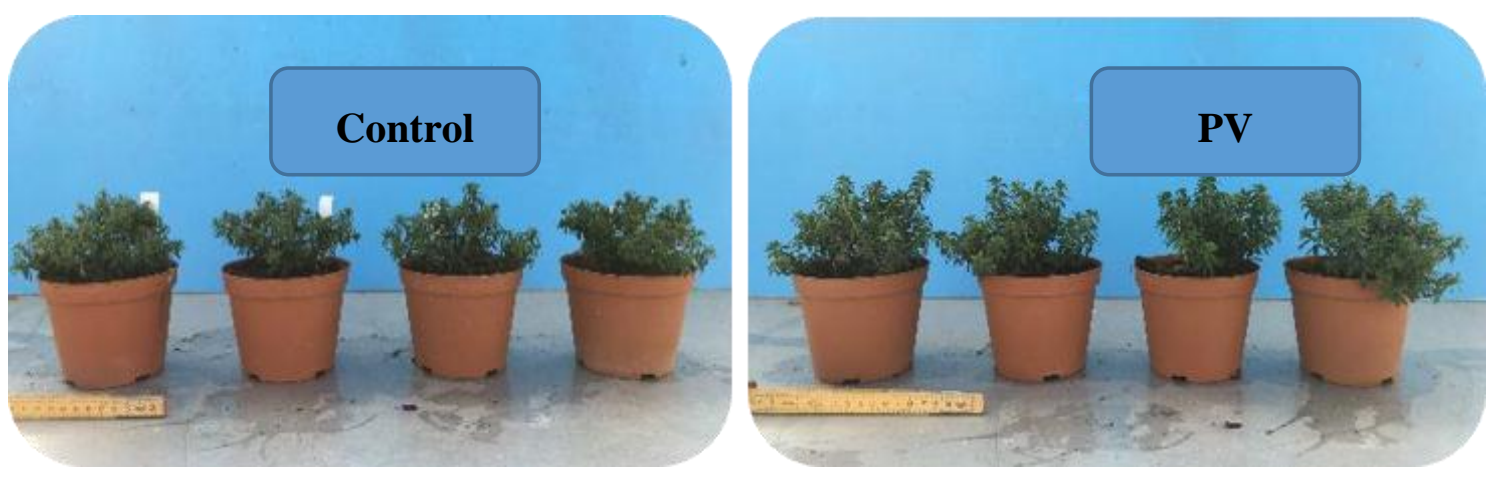

Figure 12. Iberis: control and plants under PV compared. 


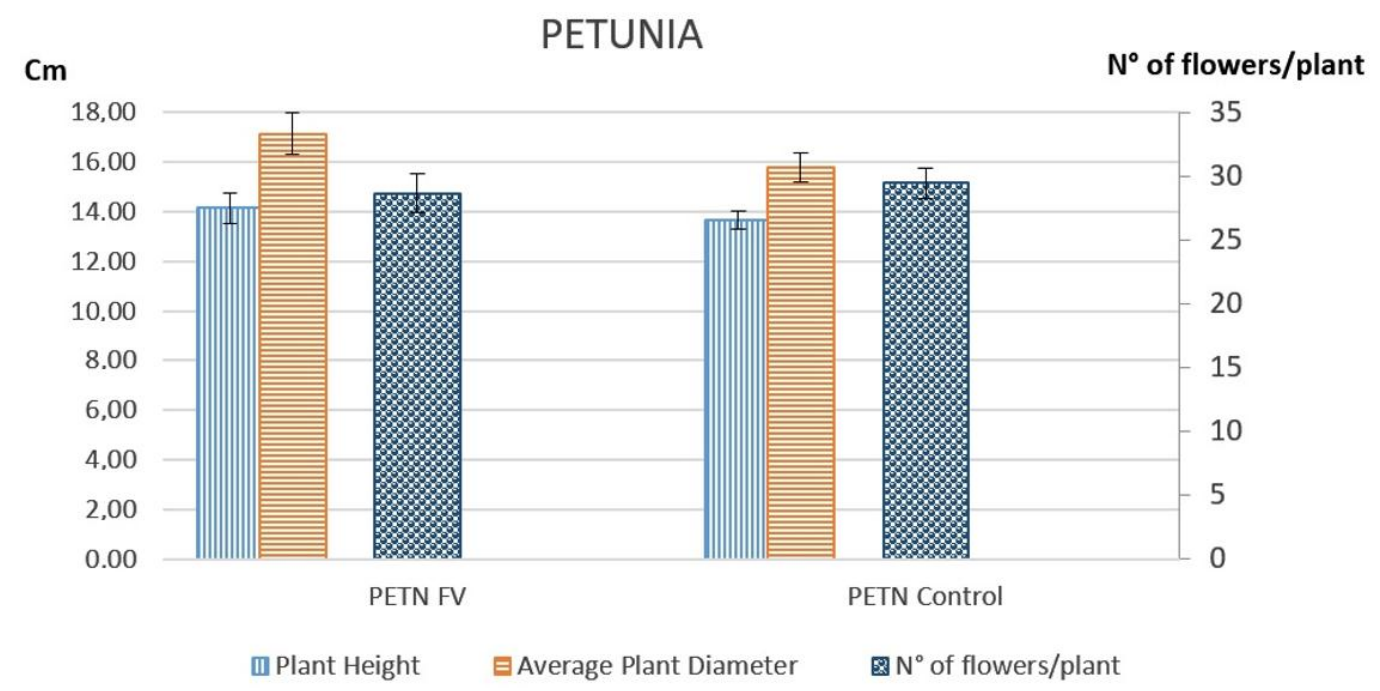

Figure 13. Petunia: analysis of plant growth parameters at the end of the trial.
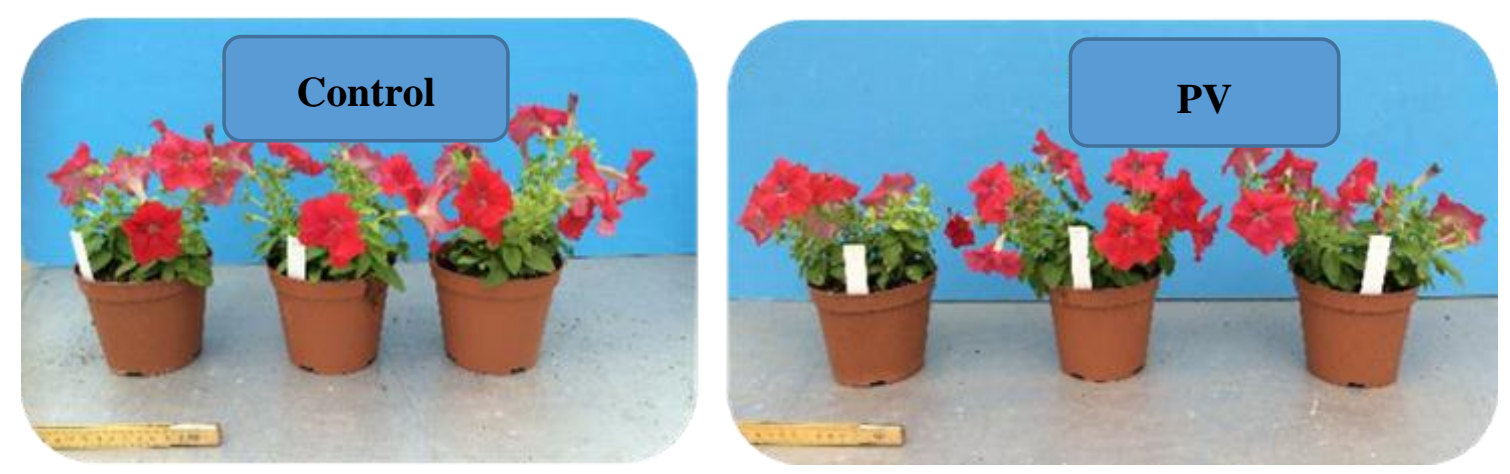

Figure 14. Petunia: control and plants under PV compared.

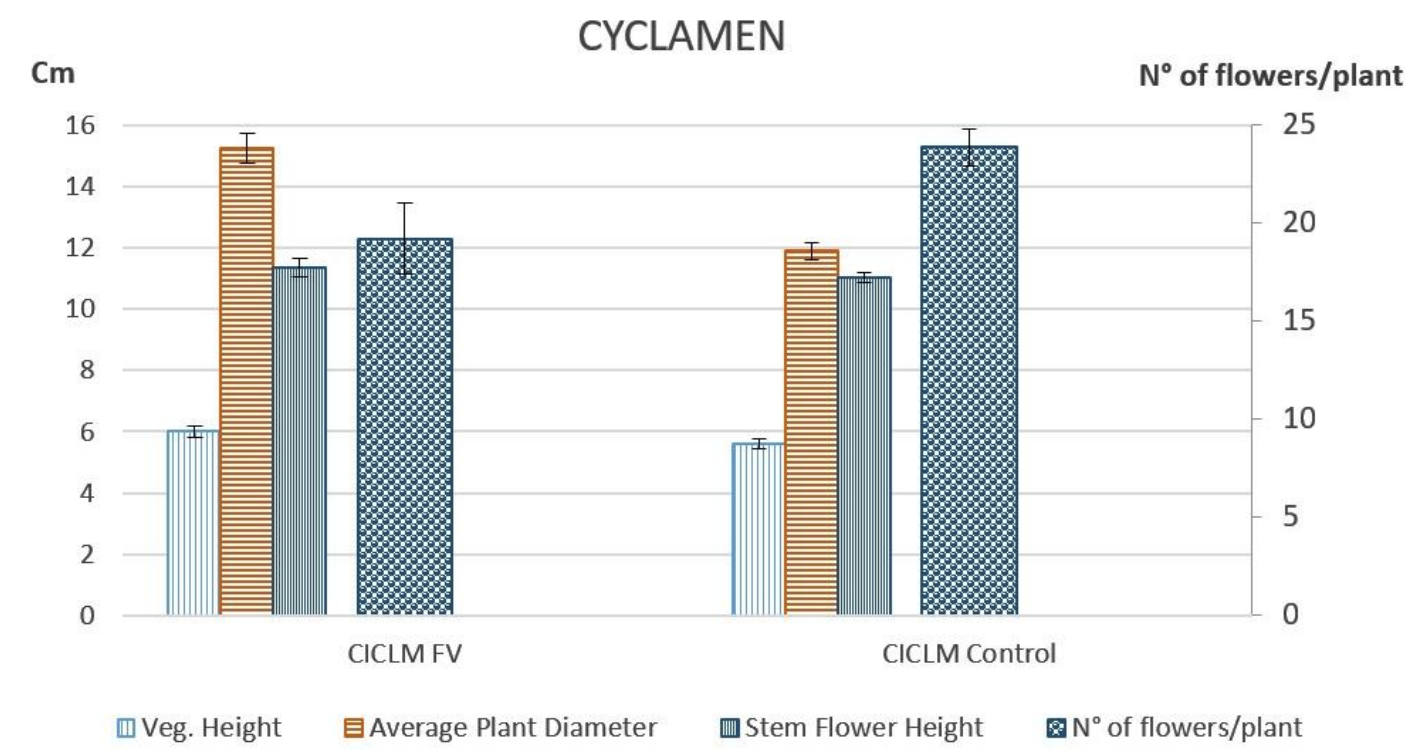

Figure 15. Mini-cyclamen: analysis of plant growth parameters at the end of the trial. 

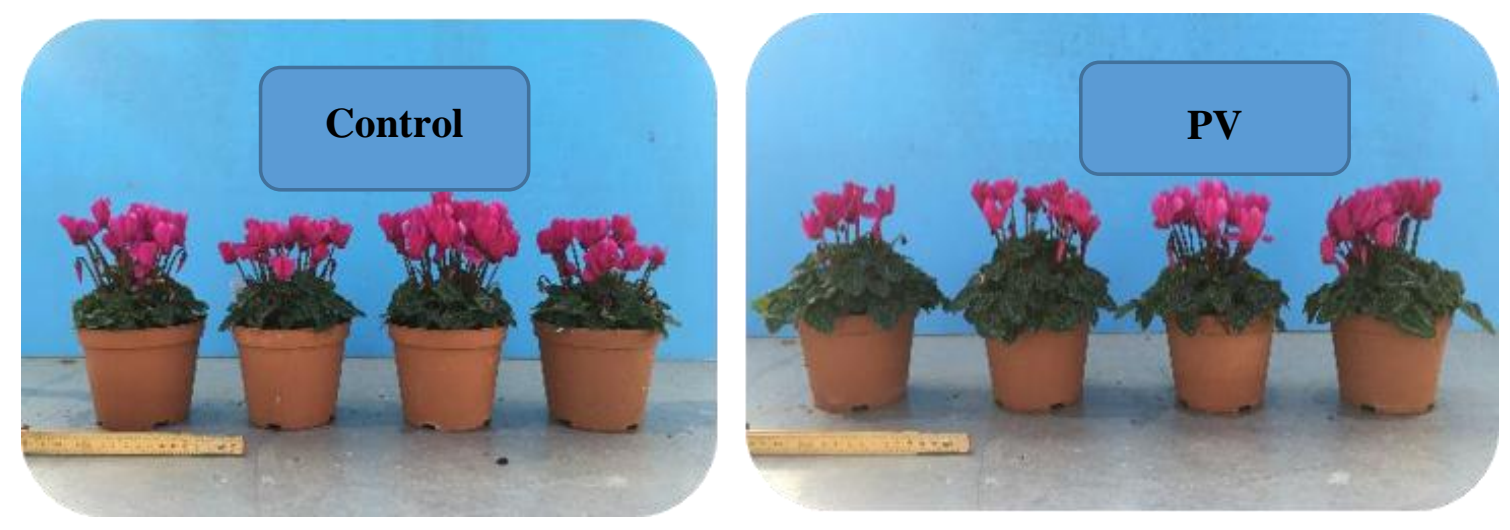

Figure 16. Mini-cyclamen: control and plants under PV compared.

\section{Discussion and Conclusions}

The success of PV plants mounted in greenhouses derives from the chance to achieve a strategic and ingenious cultivation through environmentally controlled greenhouses [41], enabling a safe and continuous production $[14,30,42]$. In modern agriculture, greenhouses embody technological solutions aimed at increasing quality and productivity of crops [18]. Specifically, the application of greenhouse technology in the floriculture sector is recording a strong growth trend around the world [14].

Higher degree of sustainability in the agricultural sector nowadays assumes an essential role in issues that concern animal biodiversity, renewable resources, and plant conservation $[43,44]$. Current agricultural systems need to contribute to eco-compatible uses, e.g., guaranteeing long-term land-use efficiency and ecosystem functions $[45,46]$. Regions that enjoy plenty of solar radiation, such as Italy, can take advantage of solar energy to provide clean and renewable energy [47]. Excluding the installation of PV panels on agricultural land, as happened in the past resulting in an effective land degradation and soil sealing [48,49], PV panels applied on the roofs of greenhouses can be considered an attractive solution $[10,41,47]$. In this way, greenhouses can make sure of rural multi-functionality, given by the production of additional energy, because of the combination of PV modules on their surface $[10,18,49,50]$. Conversely, the mounting of this kind of PV plants inevitably generates a shadow inside the structure $[30,37,41,51]$. Therefore, it is necessary to prevent shading in order not to cause an interruption on plant growth [18].

Given the wide availability of land covered by greenhouses in Italy, a thorough study on the optimization of PV greenhouse systems may be useful consequently to: (i) promote a new sustainable profile for the Italian agriculture; (ii) use clean and renewable energy; and (iii) ensure a controlled, safe, and unceasing flower production [10,50,52-57].

The opportunity for productive recovery of existing greenhouses is complex, which provides an interdisciplinary effort. The results obtained that brought out issues concerning the quantitative and qualitative reduction of the production of the plant species chosen for research cultivation in the PV greenhouse did not emerge. Considering our greenhouse model, the interesting part of the PV greenhouse coverage and its orientation (almost perfectly N-S) allowed light to enter without being disturbed by the presence of PV panels during the day. The analysis of the brightness data, with reference to the parameters of illuminance (lux accidents), global radiation and PAR (Photosynthetically Active Radiation), has provided values that were statistically higher in the sector, without being influenced by PV panels, a greater extent for lux accidents (with two times higher values) and lesser for global radiation $(30 \%)$ and PAR $(20 \%)$. These conditions have allowed plants to grow and reach anthesis (except for the iberis, not bloomed in both thesis) without great alterations from the standpoint of marketability of the commercial product. For cyclamen, some slight differences were recorded due to an increase of the surface of the light capture with a greater development of its vegetative part in the shaded area and fewer blossoms, but without affecting its commercial quality. Indeed, it is well 
known that light profoundly affects the plant life. The three most important reactions of plants to optical radiation are: photosynthesis, phototropism, and photo-morphogenesis. Photosynthesis is one of the most important biochemical processes which converts energy into chemical energy. In general plant physiology, the term Photosynthetically Active Radiation (PAR) refers to the radiation in the range of wavelengths between $400 \mathrm{~nm}$ and $720 \mathrm{~nm}$ which are useful for the photosynthesis [58,59]. The green radiations (about $550 \mathrm{~nm}$ ) have been shown important for yielding the greatest productivity and efficiency in greenhouse-grown plants, although differences could be scored according to the species. In our experiment, plants grown under PV conditions were always subjected to a lower PAR compared to the control, and the values allowed an efficient photosynthesis process making the first three weeks of cultivation more favorable. The effect of blue light $(380-520 \mathrm{~nm})$ could account for the slight phototropism and photo-morphogenesis effect above described for mini-cyclamen plants. Extensive studies would be more appropriate to verify the effect of a more extensive coverage, within restrictions imposed by the Ministerial Decree 5 May 2011 which limits the coverage of greenhouse roof with PV modules to a maximum of $50 \%$ of the total area. It affirms that "greenhouses, after the intervention, must present a relationship between the projection on the ground of the total area of the PV modules installed on the greenhouse and the projection on the ground of the total area of the greenhouse itself does not cover more than $50 \%$ ". This condition does not apply to greenhouses that have achieved qualification by the entrance into force of the Decree (13 May 2011), in pursuance of the order by TAR (Regional Administrative Court) of Latium Region n. 2890/2011 by which the effectiveness has been suspended art. 14, paragraph 2, following the Ministerial Decree of 5 May 2011). A solar system, such as the one proposed in our work, capable of varying light energy collection surface in relation to the degree of sun exposure, has the agronomic benefit of being able to shade the underlying environment in conditions of excessive brightness and to let pass lighter when it is required for the purposes of cultivated plants (or in cloudy weather). The proposed experiment can also be carried out in other territorial contexts, e.g., in difficult climatic conditions, since the microclimate of greenhouses can be easily controlled. However, from the point of view of solar energy and lighting, preliminary tests must be carried out (i) to ensure proper solar energy production especially during the winter and (ii) to use the energy produced to heat the greenhouse [60]. The present study offers a new experimental approach that guarantees a balance between crops in protected environments such as greenhouses and sustainable development [61,62], with a strong focus on renewable energies e.g., solar energy. A commercial development of such a system would have to be considered, even if the awareness of using solar energy as a supplement to the income from the floricultural production continued to be present.

Acknowledgments: This study was supported by FOTOAGRI Project-“Technological innovation for the greenhouses design and recovery using photovoltaic panels and the development of a new commercial production model for the horticultural industry", a MIPAAF's projects, transposed by D.M. No. 0019368 of 6 September 2012 (from 12 February 2013 to 31 December 2016).

Author Contributions: The contribution of the authors is shared equally.

Conflicts of Interest: The authors declare no conflict of interest.

\section{References}

1. Bulgari, R.; Cola, G.; Ferrante, A.; Franzoni, G.; Mariani, L.; Martinetti, L. Micrometeorological environment in traditional and photovoltaic greenhouses and effects on growth and quality of tomato (Solanum lycopersicum L.). Ital. J. Agrometeorol. 2015, 20, 27-38.

2. Zambon, I.; Colantoni, A.; Cecchini, M.; Mosconi, E.M. Rethinking Sustainability within the Viticulture Realities Integrating Economy, Landscape and Energy. Sustainability 2018, 10, 320. [CrossRef]

3. Demirbaş, A. Global renewable energy resources. Energy Sources 2006, 28, 779-792. [CrossRef]

4. Kralova, I.; Sjöblom, J. Biofuels-renewable energy sources: A review. J. Dispers. Sci. Technol. 2010, 31, 409-425. [CrossRef] 
5. Panwar, N.L.; Kaushik, S.C.; Kothari, S. Role of renewable energy sources in environmental protection: A review. Renew. Sustain. Energy Rev. 2011, 15, 1513-1524. [CrossRef]

6. Carlini, M.; Honorati, T.; Castellucci, S. PV greenhouses: Comparison of optical and thermal behaviour for energy savings. Math. Probl. Eng. 2012. [CrossRef]

7. Cossu, M.; Murgia, L.; Ledda, L.; Deligios, P.A.; Sirigu, A.; Chessa, F.; Pazzona, A. Solar radiation distribution inside a greenhouse with south-oriented photovoltaic roofs and effects on crop productivity. Appl. Energy 2014, 133, 89-100. [CrossRef]

8. Marucci, A.; Colantoni, A.; Zambon, I.; Egidi, G. Precision farming in hilly areas: The use of network RTK in GNSS technology. Agriculture 2017, 7, 60. [CrossRef]

9. Celik, A.N.; Muneer, T.; Clarke, P. A review of installed solar photovoltaic and thermal collector capacities in relation to solar potential for the EU-15. Renew. Energy 2009, 34, 849-856. [CrossRef]

10. Marucci, A.; Zambon, I.; Colantoni, A.; Monarca, D. A combination of agricultural and energy purposes: Evaluation of a prototype of photovoltaic greenhouse tunnel. Renew. Sustain. Energy Rev. 2018, 82, 1178-1186. [CrossRef]

11. Stanhill, G. Solar energy in agriculture. Agric. Ecosyst. Environ. 1992, 38, 352-353. [CrossRef]

12. Parker, B.F. Solar Energy in Agriculture; Elsevier: Amsterdam, The Netherlands, 1991.

13. Yano, A.; Tsuchiya, K.; Nishi, K.; Moriyama, T.; Ide, O.; Toya, M. Development of a photovoltaic module as a power source for greenhouse environment control devices and a study on its mounting in a greenhouse. J. Jpn. Soc. Agric. Mach. 2005, 67, 124-127.

14. Ganguly, A.; Ghosh, S. Modeling and analysis of a fan-pad ventilated floricultural greenhouse. Energy Build. 2007, 39, 1092-1097. [CrossRef]

15. Russo, G.; Anifantis, A.S.; Verdiani, G.; Mugnozza, G.S. Environmental analysis of geothermal heat pump and LPG greenhouse heating systems. Biosyst. Eng. 2014, 127, 11-23. [CrossRef]

16. Xu, J.; Li, Y.; Wang, R.Z.; Liu, W. Performance investigation of a solar heating system with underground seasonal energy storage for greenhouse application. Energy 2014, 67, 63-73. [CrossRef]

17. Yang, N.W.; Zang, L.S.; Wang, S.; Guo, J.Y.; Xu, H.X.; Zhang, F.; Wan, F.H. Biological pest management by predators and parasitoids in the greenhouse vegetables in China. Biol. Control 2014, 68, 92-102. [CrossRef]

18. Pérez-Alonso, J.; Pérez-García, M.; Pasamontes-Romera, M.; Callejón-Ferre, A.J. Performance analysis and neural modelling of a greenhouse integrated photovoltaic system. Renew. Sustain. Energy Rev. 2012, 16, 4675-4685. [CrossRef]

19. Djevic, M.; Dimitrijevic, A. Energy consumption for different greenhouse constructions. Energy 2009, 34, 1325-1331. [CrossRef]

20. Canakci, M.; Akinci, I. Energy use pattern analysis of greenhouse vegetable production. Energy 2006, 31, 1243-1256. [CrossRef]

21. Singh, H.; Singh, A.K.; Kushwaha, H.L.; Singh, A. Energy consumption pattern of wheat production in India. Energy 2007, 32, 1848-1854. [CrossRef]

22. Sethi, V.P.; Sharma, S.K. Greenhouse heating and cooling using aquifer water. Energy 2007, 32, $1414-1421$. [CrossRef]

23. Campiglia, E.; Colla, G.; Mancinelli, R.; Rouphael, Y.; Marucci, A. Energy balance of intensive vegetable cropping systems in central Italy. Acta Hortic. 2007, 747, 185-191. [CrossRef]

24. Marucci, A.; Pagniello, B. Simulation of the growth and the production of the tomato in typical greenhouses of the Mediterranean environment. J. Food Agric. Environ. 2011, 9, 407-411.

25. Vox, G.; Teitel, M.; Pardossi, A.; Minuto, A.; Tinivella, F.; Schettini, E. Sustainable Greenhouse Systems. In Sustainable Agriculture: Technology, Planning and Management; Salazar, A., Rios, I., Eds.; Nova Science Publishers, Inc.: New York, NY, USA, 2010; Chapter 1; pp. 1-79.

26. Hanan, J.J. Greenhouses: Advanced Technology for Protected Cultivation; CRC Press: Boca Raton, FL, USA, 1998.

27. Nelson, P. Greenhouse Operation and Management; CRC Press: Boca Raton, FL, USA, 2003.

28. Marucci, A.; Campiglia, E.; Colla, G.; Pagniello, B. Environmental impact of fertilization and pesticide application in vegetable cropping systems under greenhouse and open field conditions. J. Food Agric. Environ. 2011, 9, 840-846.

29. Colantoni, A.; Zambon, I.; Monarca, D.; Cecchini, M.; Marucci, A.; Piancentini, L.; Feltrini, S. Greenhouses plants as a landmark for research and innovation: The combination of agricultural and energy purposes in Italy. Chem. Eng. Trans. 2017, 58, 469-474. 
30. Cuce, E.; Harjunowibowo, D.; Cuce, P.M. Renewable and sustainable energy saving strategies for greenhouse systems: A comprehensive review. Renew. Sustain. Energy Rev. 2016, 64, 34-59. [CrossRef]

31. Huang, J.; Li, G.; Yang, Y. A semi-transparent plastic solar cell fabricated by a lamination process. Adv. Mater. 2008, 20, 415-419. [CrossRef]

32. Kozai, T.; He, D.; Ohtsuka, H.; Kamiya, I. Simulation of solar radiation transmission into a lean-to greenhouse with photovoltaic cells on the roof. Case study for a greenhouse with infinite longitudinal length. Environ. Control Biol. 1999, 37, 101-108. [CrossRef]

33. Marucci, A.; Gusman, A.; Pagniello, B.; Cappuccini, A. Limits and prospects of PV covers in Mediterranean greenhouses. J. Agric. Eng. 2013, 44, 1-8.

34. Stanghellini, C. La serra da utilizzatrice a fornitrice di energia? Accademia dei Georgofili 2010, 27, 1-7.

35. Tanaka, S.; Zakhidov, A.A.; Ovalle-Robles, R.; Yoshida, Y.; Hiromitsu, I.; Fujita, Y.; Yoshino, K. Semitransparent organic photovoltaic cell with carbon nanotube-sheet anodes and Ga-doped ZnO cathodes. Synth. Met. 2009, 159, 2326-2328. [CrossRef]

36. McDonald, S.A.; Konstantatos, G.; Zhang, S.; Cyr, P.W.; Klem, E.J.D.; Levina, L.; Sargent, E.H. Solution-processed $\mathrm{PbS}$ quantum dot infrared photodetectors and photovoltaics. Nat. Mater. 2005, 4, 138-143. [CrossRef] [PubMed]

37. Minuto, G.; Tinivella, F.; Bruzzone, C.; Minuto, A. Con il fotovoltaico sul tetto la serra raddoppia a sua utilità. L'informatore Agrario Supplemento 2011, 38, 30-33.

38. Stanghellini, C.; Heuvelink, E. Coltura e clima: Effetto microclimatico dell'ambiente serra. Italus Hortus 2007, 14, 37-49.

39. Li, D.H.W.; Lam, T.N.T.; Chan, W.W.H.; Mak, A.H.L. Energy and cost analysis of semi-transparent photovoltaic in office buildings. Appl. Energy 2009, 86, 722-729.

40. Minuto, G.; Tinivella, F.; Dani, E.; Gimelli, F.; Minuto, A. Serre fotovoltaiche a duplice attitudine. Colt. Protette 2010, 39, 70-77.

41. Kadowaki, M.; Yano, A.; Ishizu, F.; Tanaka, T.; Noda, S. Effects of greenhouse photovoltaic array shading on Welsh onion growth. Biosyst. Eng. 2012, 111, 290-297. [CrossRef]

42. Rogge, E.; Nevens, F.; Gulinc, H. Reducing the visual impact of 'greenhouse parks' in rural landscapes. Landsc. Urban Plan. 2008, 87, 76-83. [CrossRef]

43. Zambon, I.; Colantoni, A.; Carlucci, M.; Morrow, N.; Sateriano, A.; Salvati, L. Land quality, sustainable development and environmental degradation in agricultural districts: A computational approach based on entropy indexes. Environ. Impact Assess. Rev. 2017, 64, 37-46. [CrossRef]

44. Weissteiner, C.J.; Strobl, P.; Sommer, S. Assessment of status and trends of olive farming intensity in EU-Mediterranean countries using remote sensing time series and land cover data. Ecol. Indic. 2011, 11, 601-610. [CrossRef]

45. Zitti, M.; Zambon, I.; Mavrakis, A.; Salvati, L. The Way Toward Dispersed Metropolitan Growth: Land-use Efficiency and the Abandonment of a Mediterranean Compact Tradition. Int. J. Ecol. Dev. 2018, 33, 108-124.

46. Siciliano, G. Social multicriteria evaluation of farming practices in the presence of soil degradation. A case study in Southern Tuscany, Italy. Environ. Dev. Sustain. 2009, 11, 1107-1133. [CrossRef]

47. Ganguly, A.; Misra, D.; Ghosh, S. Modeling and analysis of solar photovoltaic-electrolyzer-fuel cell hybrid power system integrated with a floriculture greenhouse. Energy Build. 2010, 42, 2036-2043. [CrossRef]

48. Delfanti, L.; Colantoni, A.; Recanatesi, F.; Bencardino, M.; Sateriano, A.; Zambon, I.; Salvati, L. Solar plants, environmental degradation and local socioeconomic contexts: A case study in a Mediterranean country. Environ. Impact Assess. Rev. 2016, 61, 88-93. [CrossRef]

49. Marcheggiani, E.; Gulinck, H.; Galli, A. Detection of fast land. In International Conference on Computational Science and Its Applications; Springer: Berlin, Germany, 2013; pp. 315-327.

50. Tudisca, S.; Di Trapani, A.M.; Sgroi, F.; Testa, R.; Squatrito, R. Assessment of Italian energy policy through the study of a photovoltaic investment on greenhouse. Afr. J. Agric. Res. 2013, 8, 3089-3096.

51. Yano, A.; Kadowaki, M.; Furue, A.; Tamaki, N.; Tanaka, T.; Hiraki, E.; Kato, Y.; Ishizu, F.; Noda, S. Shading and electrical features of a photovoltaic array mounted inside the roof of an east-west oriented greenhouse. Biosyst. Eng. 2010, 106, 367-377. [CrossRef]

52. Asdrubali, F.; Cotana, F.; Messineo, A. On the Evaluation of solar greenhouse efficiency in building simulation during the heating period. Energies 2012, 5, 1864-1880. [CrossRef] 
53. Mekhilef, S.; Faramarzi, S.Z.; Saidur, R.; Salam, Z. The application of solar technologies for sustainable development of agricultural sector. Renew. Sustain. Energy Rev. 2013, 18, 583-594. [CrossRef]

54. Messineo, A.; Panno, D. Municipal waste management in Sicily: Practices and challenges. Waste Manag. 2008, 28, 1201-1208. [CrossRef] [PubMed]

55. Messineo, A.; Volpe, R.; Marvuglia, A. Ligno-cellulosic biomass exploitation for power generation: A case study in Sicily. Energy 2012, 45, 613-625. [CrossRef]

56. Sgroi, F.; Tudisca, S.; Di Trapani, A.M.; Testa, R.; Squatrito, R. Efficacy and efficiency of Italian energy policy: The case of PV systems in greenhouse farms. Energies 2014, 7, 3985-4001. [CrossRef]

57. Zambon, I.; Monarca, D.; Cecchini, M.; Bedini, R.; Longo, L.; Romagnoli, M.; Marucci, A. Alternative Energy and the Development of Local Rural Contexts: An Approach to Improve the Degree of Smart Cities in the Central-Southern Italy. Contemp. Eng. Sci. 2016, 9, 1371-1386.

58. Salisbury, F.B.; Ross, C.W. Plant physiology; Wadsworth: Boston, 1992.

59. Taiz, L.; Zeiger, E. Plant Physiology, 2nd ed.; Sinauer Associates Publishers: Sunderland, MA, USA, 1998.

60. Dehbi, A.; Youssef, B.; Chappey, C.; Mourad, A.H.; Picuno, P.; Statuto, D. Multilayers Polyethylene Film for Crop Protection in Harsh Climatic Conditions. Adv. Mater. Sci. Eng. 2017, 2017, 1-7. [CrossRef]

61. Garcia-Caparros, P.; Contreras, J.I.; Baeza, R.; Segura, M.L.; Lao, M.T. Integral Management of Irrigation Water in Intensive Horticultural Systems of Almería. Sustainability 2017, 9, 2271. [CrossRef]

62. Barbeau, C.D.; Oelbermann, M.; Karagatzides, J.D.; Tsuji, L.J. Sustainable agriculture and climate change: Producing potatoes (Solanum tuberosum L.) and bush beans (Phaseolus vulgaris L.) for improved food security and resilience in a canadian subarctic first nations community. Sustainability 2015, 7, 5664-5681. [CrossRef]

(C) 2018 by the authors. Licensee MDPI, Basel, Switzerland. This article is an open access article distributed under the terms and conditions of the Creative Commons Attribution (CC BY) license (http:/ / creativecommons.org/licenses/by/4.0/). 